\title{
The biotreatment of high iron containing water for aquaculture using ripe and unripe peels of plantain
}

\begin{abstract}
The ubiquitous nature and abundance of both surface and underground water resource in the Niger Delta cannot be overemphasized. Water play diverse roles in the ecosystem, including the its inevitable sustainability of the aquaculture sector. Unfortunately, actualization of clean and safe water in the Niger Delta could be problem at ic due high iron levels and acidic $\mathrm{pH}$, which makes farmer struggle to improve water quality for aquaculture suitability there by applying both empirical and instinctive measures. Untreated water having iron content of $10.81 \pm 0.11-11.44 \pm 0.12 \mathrm{mg} / 1$ with $\mathrm{pH}$ of $4.32 \pm 0.16-5.09 \pm 0.06$ was treated with ripe and unripe peels of plantain fruit. Results shows that $\mathrm{pH}$ had significant inverse relationship $(\mathrm{P}<0.01)$ with iron, hardness and BOD but direct relationship with dissolved oxygen. After 4 weeks of treatment, Iron concentration decreased as; $9.98<7.96<4.92<1.55 \mathrm{mg} / 1$ for the unripe plantain peel treatment (UPPT), and7.96<6.39<3.08<0.86mg/l for ripe plantain peel treatment $($ RPPT). Results show that there was a significant $(\mathrm{p}<0.05)$ corresponding increase in $\mathrm{pH}$ for both UPPT $(5.34>5.83>6.34>6.56)$ and RPPT $(5.53>5.59>6.55>6.70)$ respectively. All the treatments resulted in the improvement of the water quality, especially with respect to $\mathrm{pH}$ and iron. The RPPT had better efficacy compared to UPPT, but all treatment improved the suitability of the water to the conformance of suitable for aquaculture.
\end{abstract}

Keywords: aquaculture, biotreatment, iron, plantain peels, ph
Volume 3 Issue 5 - 2017

\author{
Enetimi Idah Seiyaboh,' Tariwari CN Angaye,' \\ Odangowei I Ogidi \\ 'Department of Biological Sciences, Niger Delta University, \\ Nigeria \\ ${ }^{2}$ Department of Science Laboratory Technology, Federal \\ Polytechnic of Oil \& Gas Ekowe, Nigeria
}

Correspondence: Tariwari CN Angaye, Department of Biological Sciences, Niger Delta University, Wilberforce Island, Bayelsa State, Nigeria,Tel +2347037889063

Email maktarry@yahoo.com

Received: August 02, 2017 | Published:September II, 2017

\section{Introduction}

Water playan essential role in the ecosystem because it is an obligate resource for the survival of all organisms. While water is a ubiquitous resource, its quality and aesthetic value are often impaired by either anthropogenic agent or natural phenomena. It was documented in literature that about $70 \%$ of the Niger delta is occupied with water, but access to quality water still remains a ravaging problem. ${ }^{1,2}$ While over 300 million lack access to quality water in over ten African countries, it was reported that another 1.0- 0.2 billion persons still suffer water shortage globally. ${ }^{1}$ Sequel to the fall in oil price which is the mainstay of the Nigerian economy; Agriculture including fish farming has become one of the major mantra aimed at signalling a multi-economy. Agriculture was reported to create employment with an active labour force of over $70 \%{ }^{3,4}$ Unfortunately, the suitability of water for aquaculture has become a major challenge due to organic and inorganic agents like microbial contamination and high iron content (25-8). For instance, high iron concentration has been reported to affect some vital physicochemical parameters that sustain aquatic organisms, especially fish. ${ }^{1-6}$ The application of instinctive knowledge, failure to adhere to aseptic measures and technical advice on the part of the farmer has been linked poor yield in the aquaculture sector. ${ }^{7,8}$ For instance, fish kill when farmers administer wrong and ineffective treatment without the aid of competent personnel. ${ }^{7}$ Fish kill are largely linked to infectious or non-infectious disease, and in rare cases due to mechanical trauma and excessive usage of exogenous hormone. ${ }^{5}$ Studies have shown that untreated groundwater is toxic to fresh water fish, ${ }^{6}$ in both concrete tank and earthen pond as a result of high iron levels and acidity. ${ }^{1}$ On the other hand, some farmers have applied various instinctive methods to remedy poor water quality of their homestead pond including the use of plantain bracts and leaves in what is known as pond fertilization.
Fertilization in this context refers to the application of certain synthetic and natural formulation in order to stimulate the growth of aquatic flora and fauna which act as buffer to acidic $\mathrm{pH}$ or even nutrient for fish in homestead pond. For instance, nutrients produced during fertilization, enhance the bioavailability of phytoplankton as primary producers in pond. ${ }^{9}$ The indigenous application of plantain for optimizing aquaculture water has become a common practice, though the science behind this practice yet to be unravelled. ${ }^{10}$ Several Authors have reported remedial measures to high iron and acidic water using single and double trickling filter and, ${ }^{5}$ using activated carbon from bamboo. ${ }^{11}$ Fortunately, a recent study showed that leaves, trunk and bracts of plantain were able to optimized mitigate high iron content, thereby optimizing acidic $\mathrm{pH} .{ }^{10}$ Application of water treatment technologies is constrained on the part of the farmer due to high cost of fabricating and maintaining contemporary treatment plant; in addition, In the Niger Delta, production of waste stream from plantain peels is constituting environmental problem. Hence necessitating the prospective application of plantain peels in this current study.

\section{Materials and methods}

\section{Samples collection and analysis}

Fifty litre of untreated iron-containing groundwater was collected from a $60 \pm 5 \mathrm{Ft} 60 \pm 5 \mathrm{ft}$ bore hole in near a fish farm in Yenagoa, Bayelsa state, Nigeria. Ripe and Unripe peels of plantain were collected from a roadside plantain vendor, popularly known as Bole joint, the peels were distinctly chopped to smaller unit for the biotreatment assay.

\section{Analysis of water samples}

All analysis was carried out following standard protocol. ${ }^{12}$ The water was analysed for in-situ physicochemical parameters like; Temperature, $\mathrm{pH}$, Total dissolved Solids (TDS), Dissolved Oxygen 
using portable field meter (DO-700). Biochemical Oxygen Demand (BOD5) was analysed in the laboratory using Winkler's method, Colorimetric method was used for the analysis of nitrate. Iron was analysed using the Perkin Elmer 5100 PC AA Model of Flame Atomic Absorption Spectrophotometer Spectrometer (FAAS). For microbiological analysis, Heterotrophic bacteria and fungi were enumerated by aerobic standard plate count (Pour Plate Technique), while the total and feacal coliforms were determined using Multiple Tube Fermentation Technique expressed as MPN (Most Probable Number) APHA 9222C.

\section{Experimental design}

Ten grams of triplicate samples plantain peels were weighed using weighing balance and distinctly macerated in 4 Litres of the collected water sample. The results were monitored for the aforementioned parameters weekly for a period of one month.

\section{Statistical analysis}

All emerging data were subjected to statistical analysis using Version 20 of SPSS, One Way Analysis of variance (ANOVA) was utilized for mean separation, while Duncan multiple range statistic was used to establish the significance of the observed differences at $\mathrm{P}=0.05$.

\section{Results and discussion}

As presented in Table 1, results of the water quality assessment in the control (i.e. without treatment) after one week was high in iron content $(11.44 \pm 0.12 \mathrm{mg} / \mathrm{l})$, with low $\mathrm{pH}$ value of $4.32 \pm 0.16(\mathrm{p}<0.05)$, other assessed parameters were Temperature $(26.29 \pm 0.16 \mathrm{OC})$, Dissolved oxygen $(3.07 \pm 0.02 \mathrm{mg} / \mathrm{l})$, Biochemical oxygen Demand $(1.44 \pm 0.31 \mathrm{mg} / 1)$, Total dissolved Solid $(55.80 \pm 0.14 \mathrm{mg} / 1)$, Nitrate $(2.13 \pm 0.05 \mathrm{mg} / \mathrm{l})$ and Hardness with value of $309.71 \pm 5.71 \mathrm{mg} / \mathrm{l}$ $(p<0.05)$. But after treatment with unripe plantain peels, the inverse correlation between $\mathrm{pH}$ and Iron was still observed as $\mathrm{pH}$ improved from $4.32 \pm 0.16$ to $5.34 \pm 0.04$ while iron concentration reduced from $11.44 \pm 0.12 \mathrm{mg} / 1$ to $9.98 \pm 0.26 \mathrm{mg} / 1$ The temperature was $27.86 \pm 0.04 \mathrm{OC}$; Dissolved Oxygen $4.10 \pm 0.10 \mathrm{mg} / 1$ and Biochemical Oxygen Demand of $1.36 \pm 0.12 \mathrm{mg} / \mathrm{l}$. Total Dissolved Solid (TDS), was $64.50 \pm 0.20 \mathrm{mg} / 1$, while the values of Nitrate and Hardness were $3.79 \pm 0.17$ and $293.64 \pm 0.23 \mathrm{mg} / 1$ respectively $(\mathrm{p}<0.05)$. Similarly, the treatment with ripe peels of plantain (RPPT), further improved the water quality compared to the unripe peels with $\mathrm{pH}$ of $5.53 \pm 0.04$ and iron concentration of $7.96 \pm 0.55 \mathrm{mg} / 1$ with significant difference $(p<0.05)$. In the second week, the water quality of the control indicated no significant change $(\mathrm{p}>0.05)$ in iron concentration compared to the first week $(11.44 \pm 0.12 \mathrm{mg} / \mathrm{l})$. But there was slight change in $\mathrm{pH}$ value with significant difference ranging from $4.32 \pm 0.16$ in the first week to $4.76 \pm 0.09$ in the second week $(\mathrm{p}<0.05)$. Temperature was $27.69 \pm 0.17 \mathrm{OC}$, Dissolved oxygen increased to $3.57 \pm 0.17 \mathrm{mg} / 1$, Biochemical oxygen Demand was $1.44 \pm 0.31 \mathrm{mg} / 1$, TDS and Nitrate values indicated no significant change $(\mathrm{p}>0.05)$, while Hardness $301.38 \pm 0.08 \mathrm{mg} / 1 \quad(\mathrm{p}<0.05)$. However, the treatment with unripe plantain peels (UPPT), indicated improved $\mathrm{pH}(5.83 \pm 0.03)$ and Iron $(7.96 \pm 0.05 \mathrm{mg} / \mathrm{l})$ values compared to the first week. The temperature of the unripe plantain peel treatment was $28.65 \pm 0.17 \mathrm{OC}$; while DO and BOD were $4.31 \pm 0.11$ and $1.10 \pm 0.06 \mathrm{mg} / 1$ respectively $(\mathrm{p}<0.05)$. Total Dissolved Solid was $54.17 \pm 0.11 \mathrm{mg} / \mathrm{l}$, while nitrate increased to $4.29 \pm 0.17 \mathrm{mg} / \mathrm{l}$, Hardness was $213.71 \pm 0.17 \mathrm{mg} / \mathrm{l} \quad(\mathrm{p}<0.05)$. The
RPPT further improved the water quality with $\mathrm{pH}$ value of $5.94 \pm 0.03$ with significant corresponding reduction in iron concentration of $6.39 \pm 0.23 \mathrm{mg} / 1 \quad(\mathrm{p}<0.05)$. While other parameters in the RPPT were Temperature $(28.43 \pm 0.02 \mathrm{OC})$, DO $(4.54 \pm 0.03 \mathrm{mg} / \mathrm{l})$, BOD $(1.38 \pm 0.11 \mathrm{mg} / 1)$, TDS $(47.09 \pm 0.01 \mathrm{mg} / 1)$, Nitrate and Hardness were $4.52 \pm 0.02$ and $219.76 \pm 0.13 \mathrm{mg} / 1$. In the third week, it was no significant difference in $\mathrm{pH}$ and total Iron compared to the controls of the second week $(\mathrm{p}>0.05)$.

Temperature was $26.95 \pm 0.140 \mathrm{OC}$, Dissolved oxygen was $3.57 \pm 0.17 \mathrm{mg} / 1$, Biochemical oxygen Demand was $1.44 \pm 0.31 \mathrm{mg} / 1$, TDS and Nitrate values indicated no significant change $(p>0.05)$, while Hardness $203.07 \pm 0.14 \mathrm{mg} / 1(\mathrm{p}<0.05)$. However, the treatment with unripe plantain peels (UPPT), indicated improved $\mathrm{pH}$ of $6.34 \pm 0.03$ and Iron value of $4.92 \pm 0.15 \mathrm{mg} / 1$ compared to the second week. In addition, the unripe plantain treatment had temperature of $29.25 \pm 0.26 \mathrm{OC}$; with $\mathrm{DO}$ and BOD of $4.42 \pm 0.05$ and $2.73 \pm 0.16 \mathrm{mg} / 1$ respectively $(\mathrm{p}<0.05)$. Total Dissolved Solid was $50.48 \pm 0.31 \mathrm{mg} / 1$, while nitrate was $4.62 \pm 0.21 \mathrm{mg} / 1$, and Hardness was $203.07 \pm 0.14 \mathrm{mg} / 1$ $(\mathrm{p}<0.05)$. The RPPT improved the water quality with $\mathrm{pH}$ value of $6.55 \pm 0.02$ reduced iron concentration to $3.08 \pm 0.08 \mathrm{mg} / 1 \quad(\mathrm{p}<0.05)$. While other parameters were Temperature $(28.43 \pm 0.02 \mathrm{OC})$, DO $(4.54 \pm 0.03 \mathrm{mg} / 1), \quad$ BOD $(1.38 \pm 0.11 \mathrm{mg} / \mathrm{l}), \quad$ TDS $(47.09 \pm 0.01 \mathrm{mg} / 1)$, Nitrate and Hardness were $4.43 \pm 0.05$ and $150.98 \pm 0.05 \mathrm{mg} / \mathrm{l}$.

Compared to the control, results of UPPT and RPPT indicated that in the fourth week, the $\mathrm{pH}$ and total Iron of the water sample improved significantly ( $>0.05$ ). The $\mathrm{pH}$ was6.56 \pm 0.05 and $6.70 \pm 0.07$ for UPPT and RPPT respectively, while total iron was $1.55 \pm 0.36$ and $0.86 \pm 0.04$. Temperature was $26.86 \pm 0.06$ and $27.60 \pm 0.100 \mathrm{C}$, Dissolved oxygen was $4.04 \pm 0.06$ and $4.36 \pm 0.40 \mathrm{mg} / 1$, Biochemical oxygen Demand was $2.37 \pm 0.16$ and $2.42 \pm 0.30 \mathrm{mg} / 1$, TDS values were $44.25 \pm 0.41$ and $33.97 \pm 0.10 \mathrm{mg} / 1$, while Nitrate was $4.57 \pm 0.08$ and $4.39 \pm 0.07(\mathrm{p}>0.05)$. Hardness of the water was $162.18 \pm 0.32 \mathrm{mg} / \mathrm{lfor}$ UPPT, and $110.11 \pm 0.10 \mathrm{mg} / 1$ for RPPT $(\mathrm{p}<0.05)$. The results of this research corroborate Ohimain et al. ${ }^{2}$ which confirm acidic $\mathrm{pH}$ in water with high iron content, especially in some part of the Niger Delta. Ohimain et al. ${ }^{5}$ reported $\mathrm{pH}$ of 4.39-5.17 with iron content of 5.32$9.96 \mathrm{mg} / 1$ in untreated ground water of Bayelsa State. Apart from iron and $\mathrm{pH}$ that showed inverse correlation, other parameters improved significantly $(\mathrm{P}<0.05)$ as a result of the treatment. Dissolved oxygen increased while BOD, nitrate and hardness decreased $(\mathrm{P}<0.01)$ as the treatment progressed, though the RPPT treatment indicated better results compared UPPT. The results of this study also corroborated the finding of Ohimain et al., ${ }^{2}$ which showed the plantain leaves, stem and bracts was able to significantly reduce high iron containing water with acidic $\mathrm{pH}$ after 4 weeks of treatment from $8.62-2.12 \mathrm{mg} / 1$ and 4.15-6.48 for the leaves, $8.62-1.05 \mathrm{mg} / 1$ and $4.15-6.85$ for the bracts and $8.62-0.11 \mathrm{mg} / 1$ and $4.15-7.88$ for the trunk. Ground water is often preferred for aquaculture due to the fact that it is devoid of contaminants. ${ }^{6}$ However, ground water from the study area (Niger Delta), contains high levels of iron have been found to be toxic to fish, especially fingerlings. ${ }^{6}$ Fortunately, RPPT and UPPT had resulted in decreased iron levels as well as optimized $\mathrm{pH}$. Although the mechanism of treatment is yet to be unraveled but biosorption by the plant was a suspected mechanism. Since there was improvement of $\mathrm{pH}$ as well as dissolved oxygen with a resultant decrease in BOD, hardness and nitrate. Notwithstanding, further research to validate this claim will be necessary, as well as the field trial to determine the actual dose of the treatment. 
Table I Result of water quality parameters after biotreatment with plantain peels

\begin{tabular}{|c|c|c|c|c|c|c|c|c|c|}
\hline & WK & Temp $\left({ }^{\circ} \mathrm{C}\right)$ & pH & DO (mg/l) & BOD (mg/l) & $\begin{array}{l}\text { TDS } \\
\text { (mg/l) }\end{array}$ & $\begin{array}{l}\text { Nitrate } \\
\text { (mg/l) }\end{array}$ & $\begin{array}{l}\text { Hardness } \\
\text { (mg/l) }\end{array}$ & Iron $(\mathrm{mg} / \mathrm{l})$ \\
\hline & I & $26.29 \pm 0.16 a$ & $4.32 \pm 0.16 \mathrm{a}$ & $3.07 \pm 0.02 \mathrm{a}$ & $\mathrm{I} .44 \pm 0.3 \mathrm{Ia}$ & $55.80 \pm 0.14 \mathrm{~g}$ & $2.13 \pm 0.05 a$ & $309.7 I \pm 5.7 \mathrm{Ij}$ & $1 \mathrm{I} .44 \pm 0.12 \mathrm{i}$ \\
\hline & 2 & $27.69 \pm 0.17 \mathrm{de}$ & $4.76 \pm 0.09 b$ & $3.57 \pm 0.17 b$ & $\mathrm{I} .44 \pm 0.3 \mathrm{Ia}$ & $55.80 \pm 0.09 g$ & $2.13 \pm 0.05 a$ & $30 I .38 \pm 0.09 i$ & $1 \mathrm{I} .44 \pm 0.1 \mathrm{li}$ \\
\hline \multicolumn{10}{|l|}{ Control } \\
\hline & 3 & $26.95 \pm 0.14 b$ & $4.76 \pm 0.09 b$ & $3.57 \pm 0.18 b$ & $\mathrm{I} .44 \pm 0.3 \mathrm{Ia}$ & $59.80 \pm 0.10 \mathrm{~h}$ & $3.33 \pm 0.05 c$ & $300.98 \pm 0.13 \mathrm{i}$ & $10.8 \mathrm{I} \pm 0.1 \mathrm{Ih}$ \\
\hline & 4 & $28.7 \mathrm{I} \pm 0.08 \mathrm{~g}$ & $5.09 \pm 0.06 c$ & $4.07 \pm 0.02 c$ & $2 . I I \pm 0.1 I c$ & $6 \mathrm{I} .64 \pm 0.20 \mathrm{i}$ & $3.73 \pm 0.30 d$ & $300.98 \pm 0.13 \mathrm{~h}$ & $10.8 \mathrm{I} \pm 0.1 \mathrm{Ih}$ \\
\hline & I & $27.86 \pm 0.04 \mathrm{e}$ & $5.34 \pm 0.04 d$ & $4.10 \pm 0.10 d$ & $1.36 \pm 0.12 \mathrm{a}$ & $64.50 \pm 0.20 \mathrm{j}$ & $3.79 \pm 0.17 d$ & $293.64 \pm 0.23 \mathrm{i}$ & $9.98 \pm 0.26 \mathrm{~g}$ \\
\hline \multirow{3}{*}{$\begin{array}{l}\text { Unripe } \\
\text { Peels }\end{array}$} & 2 & $28.65 \pm 0.17 f g$ & $5.83 \pm 0.03 f$ & $4.3 \mathrm{I} \pm 0.1 \mathrm{Id}$ & $1.10 \pm 0.06 a$ & $54.17 \pm 0.1$ If & $4.29 \pm 0.17 \mathrm{de}$ & $213.7 I \pm 0.17 \mathrm{e}$ & $7.96 \pm 0.05 f$ \\
\hline & 3 & $29.25 \pm 0.26 \mathrm{~h}$ & $6.34 \pm 0.03 g$ & $4.42 \pm 0.05 e$ & $2.09 \pm 0.05 c$ & $50.48 \pm 0.3 \mathrm{le}$ & $4.62 \pm 0.2$ If & $203.07 \pm 0.14 d$ & $4.92 \pm 0.15 d$ \\
\hline & 4 & $26.86 \pm 0.06 b$ & $6.56 \pm 0.05 \mathrm{~h}$ & $4.96 \pm 0.06 f$ & $2.37 \pm 0.16 c$ & $44.25 \pm 0.4 \mathrm{Ic}$ & $4.57 \pm 0.08 f$ & $162.18 \pm 0.32 c$ & $1.55 \pm 0.36 \mathrm{~b}$ \\
\hline & I & $27.8 I \pm 0.1 \mathrm{Ide}$ & $5.53 \pm 0.04 \mathrm{e}$ & $4.04 \pm 0.06 c$ & $1.53 \pm 0.04 c$ & $67.28 \pm 0.19 d$ & $4.20 \pm 0.10 d$ & $250.40 \pm 0.35 g$ & $7.96 \pm 0.55 f$ \\
\hline & 2 & $28.43 \pm 0.02 f$ & $5.94 \pm 0.03 f$ & $4.54 \pm 0.03 e$ & $\mathrm{I} .38 \pm 0.1 \mathrm{Ia}$ & $47.09 \pm 0.01 \mathrm{~d}$ & $4.52 \pm 0.02 e$ & $219.76 \pm 0.13 f$ & $6.39 \pm 0.23 e$ \\
\hline \multicolumn{10}{|l|}{ Ripe Peels } \\
\hline & 3 & $27.42 \pm 0.03 c$ & $6.55 \pm 0.02 \mathrm{~h}$ & $4.55 \pm 0.02 \mathrm{e}$ & $2.21 \pm 0.18 c$ & $40.69 \pm 0.0 \mathrm{lb}$ & $4.43 \pm 0.05 \mathrm{de}$ & $150.98 \pm 0.05 b$ & $3.08 \pm 0.08 c$ \\
\hline & 4 & $27.60 \pm 0.10 c$ & $6.70 \pm 0.07 i$ & $4.35 \pm 0.40 \mathrm{e}$ & $2.42 \pm 0.30 c$ & $33.97 \pm 0.10 \mathrm{a}$ & $4.39 \pm 0.07 \mathrm{de}$ & $110.11 \pm 0.10 \mathrm{a}$ & $0.86 \pm 0.04 a$ \\
\hline
\end{tabular}

Keys: Data were expressed as mean \pm Standard Deviation, differences in alphabetical letters indicates significant difference.

\section{Conclusion}

The quality of water is a vital and inevitable requirement for an aquaculture system. Regrettably, the quality of groundwater sample in this study which is often used in homestead pond from the Niger Delta, is characterized by high concentration of iron with corresponding acidic $\mathrm{pH}$. This could cause fish kill, which is often a threat to the aquaculture sector. Fortunately, the biotreatment of the water with ripe and unripe plantain peels resulted to significant reduction in iron $(\mathrm{P}<0.05)$, with an improved $\mathrm{pH}(\mathrm{P}<0.01)$ to meet the threshold standard required by WHO limits/standards for safe water. Based these finding, and previous research on the efficacy of plantain tissues we therefore recommend the field trial of plantain the biotreatment of high iron containing acidic water and to also ascertain the actual treatment mechanism and efficacy.

\section{Acknowledgements}

None.

\section{Conflict of interest}

The author declares no conflict of interest.

\section{References}

I. Ohimain E,Angaye TCN. Iron levels other selected physicochemical and microbiological Properties of earthen and concrete catfish ponds in central Niger Delta. Int Jour of Biol \& Biomed Sci. 20 I4;3(5):04 I-043.

2. Ohimain E, Angaye TCN, Okiongbo K. Removal of Iron, Coliforms and Acidity from Ground Water Obtained from Shallow Aquifer Using Trickling Filter Method. Jour of Envt Sci \& Engr. 20I4;2:549-555.

3. Nigeria National Aquaculture Strategy. India: Federal Department of Fisheries, Formally approved by Government; 2009. 18 p.

4. Federal Department of Fisheries (FDF) Fisheries Statistics of Nigeria (19952007). 4th ed. Publication of the Federal Department of Fisheries; 1995.

5. Ohimain E, Angaye TCN, Okpeku N. The challenge of non-infectious diseases in catfish farming. The Jour of Vet Sci. 20 I 4; I I 5:344-349.

6. Ohimain E, Angaye TCN, Inyang IR. Toxicological Assessment of Groundwater Containing High Levels of Iron against Fresh Water Fish (Clariasgariepinus). Am Jour of Envt Prot. 2014;3(2):59- 63.

7. Ohimain EI,Angaye TCN, Ofongo RTC.Prevalence of Catfish Diseases in Bayelsa State:A Case Study of Kolokuma/ Opokuma Local Government Area (KOLGA), Nigeria. The Jour of Vet Sci. 20 I 3; I 14:259-266. 
8. Ohimain El, Inyang IR, Angaye TCN. The Challenge of Microbial and Parasitic Infections in Catfish Farming. The Jour of Vet Sci. 2013; I 14:30 I309.

9. Brunson, BM, Stone N, Hargreaves J. Fertilization of Fish Ponds. Southern Regional Aquaculture Center, SRAC Publication No. 47I; 1999.

10. Ohimain E, Angaye TCN, Oduah AA. Biotreatment of acidic and high iron containing groundwater for aquaculture using plantain (Muso paradisiaca) tissues. Am Jour of Envt Prot. 2014;3(5):59-63.
II. Ujile AA, Joel FO.Adsorption process of Iron (III) from borehole water on activated carbon from Nigerian Bamboo. Int Jour of Engr Sci \& Techno. 20|3;5(6): | 32|-|33|.

12. Official methods of analysis. I6th ed.USA:Association of Official Analytical Chemists (AOAC); 1995. 